\title{
Ngrowo Oral Literature as an Alternative History of Tulungagung
}

\author{
M S Rizal ${ }^{1}$, J Wijayanti $^{2}$, M Abadi $^{3}$ \\ 1,2,3 Universitas Brawijaya, Malang, Indonesia \\ $\left\{{ }^{1}\right.$ maulfi_rizal@ub.ac.id, ${ }^{2}$ jamilawijayanti@ub.ac.id, ${ }^{3}$ machrus_abadi@ub.ac.id $\}$
}

\begin{abstract}
The existence of oral literature in several cultures, especially traditional societies, is considered very important because they only know literature in one form. The forms of oral literature are spread in various regions in Indonesia and one of them is in Tulungagung. A systematic and in-depth study of the structure of swamp-based folklore in Tulungagung and the function of folklore for the surrounding community needs to be done. This is because all this time, the history of Tulungagung has been limited to folklore based on figures or inheritance in Tulunggung, while historical excavation based on stories based on regional topography has not been carried out so that it has an impact on incomplete historical descriptions or origins the proposal of Tulungagung and so far, environmental wisdom stored in the treasures of regional folklore tends to be marginalized by modern paradigms and sciences so that people tend to override the function of folklore for them. The structure of folklore is analyzed using Levi-Strauss structural theory, while the function of folklore uses the function theory of Alan Dundes. The data obtained in this study uses the technique of unstructured interviews with informants in accordance with predetermined criteria and observations at the place where the folklore originated. The results of the study concluded that swamp-based folklore in Tulungagung has a connection with the history of the establishment of Tulungagung Regency and functions as a social control, a means of increasing solidarity, a form of gratitude to God, and as a certifier of certain cultures.
\end{abstract}

Keywords: Oral Literature, Structural, Functional, Tulungagung

\section{INTRODUCTION}

Tulungagung is one of the districts located in East Java Province. Historically, before becoming Tulungagung Regency, people called it the Ngrowo District. This is because most of the area is in the form of swamps. This is the background of oral literature that developed in this area is folklore that is still associated with the surrounding environment, namely swamps and rivers.

The district of tulungagung, which is mostly in the form of swamps, certainly stores oral literature. The oral literature is certainly not far from the geographical location of the area in the form of swamps. In eastern Tulungagung there are dim swamps located in Rejotangan subdistrict, swamp swamps (mixed swamps), and clear swamps (bedalem swamps). The three examples of folklore are related to the events surrounding the birth of the folklore so that from these folktales can be seen the history of the formation or naming of places around the folklore originating. 
Much of the excavation of oral literature has been carried out in Tulungagung. Many folklore developed in Tulungagung Regency, for example the Origin of the Lembu Peteng River, the Legend of Batu Joko Budeg, and the Roro Kembang Sore and the History of the Spear of Kyai Upas. However, oral literature in Tulungagung which developed in swamp areas has so far not been explored. This is an interesting thing to explore oral literature that develops in swamp areas in Tulungagung Regency. This is because folklore that develops in an area must be related to the characteristics inherent in the area, for example the topography of the region, someone's heroic legend, so that it has an impact on naming areas in most of Java identical to folklore that developed in the area.

In addition to containing certain historical values, folklore also has functions and values for the user community. Oral literature is a national cultural heritage and still has values that should be developed and utilized for the life of the present and the future, among others, in relation to fostering literary appreciation. Oral literature has also long served as a vehicle for understanding ideas and inheriting values that grow in society. In fact, oral literature has for centuries served as the basis for communication between the creator and the community, in the sense that creation based on oral will be easier to associate because there are elements known in society [1]. Oral oral literature has an important role, not only in terms of fostering and developing regional literature, but also important in fostering and developing Indonesian literature [2]. Because it is part of oral literature, folklore also has the same roles and functions as oral literature for the development of literature or for the people who use folktales.

Based on the explanation above, a systematic and in-depth study of the structure of swamp-based folklore in Tulungagung and the function of folklore for the surrounding community needs to be done. This is said because: first, all this time the search for the history of Tulungagung is limited to folklore based on figures or inheritance in the district of Tulunggung, while the historical excavation based on the story based on the topography of the region has not been done so that it has an impact or the origin of the Regency of Tulungagung. Second, environmental wisdom stored in the treasures of regional folklore tends to be marginalized by modern paradigms and science so that people tend to override the function of folklore for them. Thus, folklore is only regarded as a myth or entertainment story alone does not have any value and function. The people should be able to take the values contained in folklore and get benefits based on the function of folklore for them.

\section{RESEARCH METHODS}

The object of this research is folklore that developed in swamp areas in Tulungagung Regency. The data sources of this study are: first, oral texts and written folklore set in swamps in Tulungagung Regency; second, informant; and third, documents (from observations). The informants of this study were direct actors / speakers of swamp-based folklore in Tulungagung District, namely dukun, kuncen, and village elders. The research data was collected by unstructured interview techniques and observations. The interview technique in this study was used to record swamp-based folklore data in Tulungagung District which cannot be recorded through observation[3]. While the observation technique used in this study is the technique of non-participation observation or ordinary observation.

The data analysis technique of this research uses content analysis and descriptive analysis. Content analysis is a research technique for making inferences that can be replicated and validated by paying attention to their constellation[4]. The content analysis technique is used because the data processing is emphasized in the content review in accordance with the focus 
of the research to be discussed. The content review of the existing data is described descriptively.

\section{RESULTS AND DISCUSSION}

The surface structure of Ngrowo oral literature first tells the story of the legend of the embryo of Tulungagung, namely the story of the formation of swamps into a city. this story of the Tulungagung area used to be in the form of swamps so that the surrounding community referred to it as Ngrowo. The name Ngrowo is caused by its natural condition which is still in the form of swamps and river paths being used as the main traffic called the Ngrowo river until now. Ngrowo in ancient times was a swamp that had not been touched by the population. But the people who choose to live in the swamp of their lives are very prosperous and rich. Because every day they look for fish in swamps and the results they sell are very large. In the past, flooding often happened because there was no source of good recharge and in every rainy season rainwater could not be properly accommodated. But along with the development of the times and advances in technology, the government mobilized the making of drainage channels in the form of tunnels so that they could be allocated well and made the area not flooded again.

In the second episode, the story of Lawadan Inscription from the Kingdom of Daha. The King of the last Daha Kingdom told that Sri Kretajaya - known as Prabu Dhandang Gendis gave a Lawadan inscription as a form of effort to defend the Daha Kingdom for his territories, especially in the swamp area called Ngrowo. The Lawadan inscription was written as a gift to Lawadan soldiers in helping the Daha Kingdom. In the sense that at that time it was a form of effort to support the Kingdom of Daha from the war that occurred at that time. I from the Lawadan inscription itself is a story about land tax exemption and acceptance of privileges such as the earth civilization.

The third episode is about the Story of the Guardian White Demon Guardian Ngrowo. In the past, people who lived in the Ngrowo area believed that in the area there was a guardian stealth called Bajul Putih. According to the local myths, Bajul Putih is the ruler of the Ngrowo area which is now Karang Sawit and Lawadan. Bajul Putih itself is a messenger from the Queen of South. White Bajul can display its form as a human being but by revealing itself in the appearance of crazy people. White Bajul in the form of animals that appear occasionally and only for an instant. People often do a performing art in the form of tayup where there are many female dancers. So that the stealth sometimes appears by changing its form into a human being and tempting female dancers at the tayupan event.

Surface Structure Ngrowo oral literature tells the story of the Legend of Kyai Upas. In the first episode about Baru Klinting. Kyai Upas itself is an embodiment of a heirloom that was once a tangible snake which was cut off by its tongue so that the tongue of the dragon snake became an heirloom. According to legend, the dragon snake has a new name Klinting. Before becoming a dragon snake, it was in the form of wood which had magical power. He turned into a figure of a dragon and grew up living in a swamp. Until one day he asked his mother about his father's figure. Then, he traveled to look for his meditating father on Mount Merapi. The figure of the father he was looking for on Mount Merapi was Ki Wonobojo. However, when he met his father he was given a challenge to circle Mount Merapi to be recognized as his son. When almost circling Mount Merapi with his tongue, Ki Wonobojo cut Klinting's new tongue so that he transformed into a heirloom which until now was named Kyai Upas.

The second episode tells Ki Ajar Mangir. In the history of the legend, in Tulungagung there is an inheritance called Kyai Upas. Kyai Upas is actually a weapon owned by Ki Ajar 
Mangir given by his father, Ki Wonobojo. It was told that during the reign of the King of Mataram, Ki Ajar Mangir opposed his presence. The king of Mataram also made a strategy by telling his daughter to tease Ki Ajar Mangir. Because of her beauty, Ki Ajar Mangir was melted and fell in love with the daughter of the King of Mataram. For years, finally married Ki Ajar Mangir's wife told him that he was actually the daughter of the King of Mataram. Finally, with reluctance Ki Ajar Mangir accepted this fact and with good intentions he wanted to be sowan - giving worship to his in-laws. But upon arrival in the kingdom, Ki Ajar Mangir was not welcomed by the royal guards because he was carrying Kyai Upas. Even when delivering sungkem to his in-laws, Ki Ajar Mangir was framed when Ki Ajar Mangir sungkem's head to his father-in-law was knocked into the dampar - the king's seat - and died so that Kyai Upas dodged. It is said that Kyai Upas who was darting away went to Popoh Beach and finally stuck to the Lawadan Inscription.

Surface Structure of both oral literature Ngrowo tells the story of Sedah Mirah. The first episode tells the story of the Beginning of Mirah's Sad Story. In the Sedah Mirah story, it is told that this sad is a student from Kyai Mantyasih who came from Mount Kendeng. Sedah Mirah proved to be in love with the well-known swordsman Guntur Geni from the kingdom of Mangir. Long story short, Sedah Mirah and Pendekar Guntur Geni are married. Then whoever wants to harm, both of them are given poison until they finally realize what they have done. But everything is already done. Swordsman Guntur Geni felt he could not accept anyone unless he was a warrior who was also a human, if he accepted another figure it would be considered to have forced his consciousness to go. Because when he was with Sedah Mirah, he did it when he was drunk. So that after realizing and knowing that Sedah Mirah was pregnant, Sedah Mirah was dumped in the east.

The second episode tells of Prince Ronggo Jumeno. In the story of the origin of the city of Madiun, Prince Ronggo Jumeno, who is the Duke of Madiun, has a very big ambition, which is to unite the regions in the archipelago, especially East Java. Jumeno Ronggo with his students Kyai Jugil Awarawar wants to conquer Mataram. Jumeno Ronggo faces Ki Ageng Wonoboyo. But in the fight, Kyai Jugil Awarawar was killed by Nyai Gumbreg.

The third episode tells about the role of Sedah Mirah. Sedah Mirah, who was exiled to the area in East Java, felt she wanted to give birth to the child she was carrying. He went to an area that had not been touched by many people. Long story short, Sedah Mirah gave birth without help from anyone in the cave. Elsewhere, there is a Babon who is also giving birth. However, the child of the Babon died. The baboon was very sad and ran to and fro while shouting and carrying his child. Until the Babon arrived in the cave where the Mirah Sedah gave birth. Seeing the Sedah Mirah child, the Babon exchanged his dead child with the Sedah Mirah child.

After Sedah Mirah realized from being unconscious, she was surprised because she had given birth to a Babon child. Sedah Mirah can only be silent about the fate that befell her. The Mirah Sedah baby brought by the Babon lives in the midst of the Babon family. The baboon is very fond of baby Sedah Mirah. He cared for and raised like his own child.

Two years after the incident happened, Sedah Mirah was still in nothingness. Her maternal instincts say that her child is not a baboon. As usual, Sedah Mirah is looking for edible fruits. And accidentally, he caught a swarm of Baboons. And Sedah Mirah felt awkward when she saw a baby in the collection of Babons. Sedah Mirah approached the baby. And strangely, the Babon collection didn't block the Sedah Mirah step at all. As if knowing that his biological mother approached him, the bai smiled happily. Then the Babon took away the baby Sedah Mirah. Sedah Mirah was relieved because she had met her child. And then he decided to end his life at that place. 
The fourth episode tells about the Source of Life. The Sedah Mirah place ended its life and gave rise to a spring that never dried up. So that it can be utilized by the surrounding community. The water source is maintained and cared for by the local community. The source of the spring brings many visitors. Sedah Mirah, who is indeed a female warrior, is able to organize and lead the community. Natural power, once a month Babon groups who guard Sedah Mirah children always come to visit the source of the spring.

Structure In Ngrowo oral literature consists of: first, Mytheme in the Legend of the Tulalagung Bakal; second, Mytheme in the Legend of Kyai Upas; third, the Early Mirah Mhyteme; fourth, Mhyteme Prince Ronggo Jumeno; fifth, the Mhyteme of the Mirah Role; sixth, the mhyteme of the source of life.

Analysis of Function of Folklore in Ngrowo oral literature has various functions. Some of the folklore present in the community is a folklore that impresses in people's lives. Folklore was born and grew up with the community so that most of them influenced the community. In folklore in Tulungagung about the forerunner of the city of folklore can have a function as an increase in solidarity of a group because in the story explains the origin of the region. Where the area of the swamp originally turned into land with a guardian usually called Bajul Putih. Continuing with the story of the White Bajul which is considered a guardian of the area, the function of folklore is used as providing a pleasant escape from reality. With the story developing, stealth Bajul Putih is received by the community and even invited to have fun together. For example in the following paragraph:

People often do a performing art in the form of tayup where there are many female dancers. So that the stealth sometimes appears by changing its form into a human being and tempting female dancers at the tayupan event.

In addition to the story of the embryo of Tulungagung, in the story of Kyai Upas the value of the function of folklore can be taken as increasing social sanctions to behave or give punishment. With the storyline that tells Baru Klinting with his desire to find his true identity and be destroyed by his own father. Then spread to the story of Ki Ajar Mangir who had Kyai Upas and was disliked by the King of Mataram then killed. This makes it a lesson for people to be more careful in their social life.

Aside from being an increase in solidarity and social control for the people who have the story, oral literature that developed in the Ngrowo area in Tulungagung Regency also functions as a gesture of gratitude or gratitude to God or their ancestors who have taken care of the community and provided abundant sustenance. These thanksgiving and thanks were manifested in the rituals carried out by the surrounding community, including the Mburet Lake and the Kyai Upas heritage caravan which every year was held to celebrate Tulungagung Regency Anniversary. The main ritual is Jamasan Kyai Upas. In addition to having thanksgiving and gratitude, the Jamasan Kyai Upas ritual also functions as a talak bala ceremony to avoid all disasters and dangers both for the Tulungagung Regency and Indonesia as a whole.

In its context, the story of Sedah Mirah serves as an endorsement of culture, where at that time a warrior had to marry a warrior too. So if there is a conflict or violation, it must be exiled to a distant place. In this case, swordsman Guntur Geni could not accept Sedah Mirah as his wife so he alienated the Sedah Mirah which was pregnant to a place far east.

"When Sedah Mirah kyai Mantyasih students from Mount Kendeng proved to be in love with the warrior Guntur Geni who was known in the kingdom of Mangir. Whoever started and gave poison, when the two became beksan (Menantu) until it became rusty, when the two realized they were visible but already Already, Swordsman Guntur Geni cannot accept people except 
warriors who are also human, or it is considered to have forced his consciousness to continue but still with Sedah Mirah (not of his own will) who is drunk when he is pregnant."

Sedah Mirah, who was then separated from her child, decided to end his life after being able to meet his child for a moment.

"As usual Sedah Mirah is looking for edible fruits without accidentally seeing a group of baboons bathing in the lower source east of the cave where Mirah Sedah gave birth, there is something strange, in the middle of the baboon, there is a small child from Sedah Mirah born 2 years ago Slowly Mirah approached and strangely the baboons did not interfere just like giving a way so that Sedah Mirah could approach the 2-year-old baby.The power of the creator of Gusti who gave the miracle the child was approached smiling like his instincts the baboons showing his teeth not yet grown as if with his friend. Babies captured by Babon (his mother) were taken away from Sedah Mirah. Relieved Sedah Mirah could meet the atmosphere of the incident, then decided to end his life in a place near the source. "

\section{CONCLUSIONS}

Based on folklore that developed around swamp springs located in the Tulungagung area, it can be concluded that developing folklore tells the story of the closure of springs which will later be used as agricultural land or the center of civilization. A story that develops historical stories mixed with fantasy stories, meaning that the story contains evidence that shows the truth of the story. However, it does not require the possibility that there is a fantasy story that makes little sense in it. This can be realized because fairy tales themselves are fantasy stories that are 'ordered by people'.

Based on the folklore that developed in Mburet Lake can be concluded that there is a connection between the story that developed in Tulungagung with the story of Geger Mangir. The story of Ki Ageng Mangir or in the Tulungagung version is called Ki Ajar Mangir, Baru Klinting, and Panembahan Senopati. This Klinting New Story has a story narration similar to Tarzan or Mogli. So, Baru Klinting is a Javanese Tarzan or Mogli version, because Baru Klinting is a baby raised by Babons in the forest. The new childhood of Klinting, which was raised by Babon, is what makes him immune and powerful. Baru Klinting is not a snake like the story that has been developing so far. This snake is just a sanitary form for Baru Klinting which lives in a low, marginal social strata, and its presence cannot be accepted by the community. This is because he came from an affair with Guntur Geni and Sedah Merah. Later when Baru Klinting was recognized as a child and his presence was acceptable, Baru Klinting changed to Kyai Upas. The Kyai Upas here is interpreted as someone who has extraordinary speech skills, he may be a good orator or a reliable negotiator, coupled with his good kanuragannya ability he became a warrior who fought alongside Ki Ajar Mangir. Up to Mangir's commotion, after Ki Ajar Mangir was killed by his in-laws. Baru Klinting returned to Popoh, and died at Waladan.

\section{REFERENCES}

[1] Rusyana, Yus. 1996. Tuturan Tentang Pencak Silat dalam Tradisi Lisan Sunda. Jakarta:Yayasan Obor Indonesia.

[2] Hakim, Amir. 1993. Struktur Sastra Lisan Kerinci. Jakarta: Depdikbud.

[3] Sudikan, Setya Yuwana. 2001. Metode Penelitian Sastra Lisan. Surabaya: Citra Wacana

[4] Krippendorff, Klaus. 2004. Content Analysis: An Introduction to Its Metodology 
(Second Edition). London: SAGE Publications.

[5] Bascom, William R.1965. The Form of Folklore: Prose Narratives. The Hague: Mouton.

[6] Danadjaya, James.2002. Folklor Indonesia. Ilmu Gosip, Dongeng, dan lain-lain. Jakarta: Grafiti Pres.

[7] Dundes, Alan.1965. The Study of Folklore. Englewood Cliffs, N,J: Prentice-Hall,Inc.

[8] Finnegan, Ruth. 1979. Oral Poetry. London: Cambridge University Press.

[9] Hartoko, Diek dan B Rahmanto. 1986. Pemandu dalam Dunia Sastra. Yogyakarta: Kanisus.

[10] Hutomo, Suripan Sadi. 1991. Mutiara Yang Terlupakan. Jawa Timur: HISKI.

[11] Kridalaksana, Harimurti. 1984. Kamus Linguistik. Jakarta: Gramedia.

[12] Nurgiyantoro, B. 2013.Sastra Anak: Pengantar Pemahaman Dunia Anak. Yogyakarta: Gadjah Mada University Press.

[13] Semi, M. Atar.1993. Metode Penelitian Sastra. Bandung: Angkasa.

[14] Ahimsa-Putra, Heddy. 2009. Strukturalisme Levi-Strauss: Mitos dan Karya Sastra. Yogyakarta: Keppel Press. 